\title{
Preferensi Konsumen dan Pedagang Mi Bakso terhadap Mi Basah Jagung Teknologi Ekstrusi
}

\author{
Consumer and Meatball-Noodle Seller Preferences on Wet Corn Noodle Produced \\ by Extrution Technology
}

\section{Nurheni Sri Palupi ${ }^{1 *}$, Feri Kusnandar ${ }^{1}$, Tjahja Muhandri ${ }^{1}$, Gema Buana Putra ${ }^{1}$}

\author{
${ }^{1}$ Departemen Ilmu dan Teknologi Pangan, Fakultas Teknologi Pertanian, Institut Pertanian Bogor \\ Jl. Kamper, Kampus IPB Darmaga, Bogor 16680
}

\begin{abstract}
ABSTRAK
Mi basah jagung yang dihasilkan melalui teknologi ekstrusi mempunyai keunggulan mudah diaplikasikan untuk industri kecil karena investasi terjangkau, dan dapat digunakan untuk produksi mi basah menggunakan 100\% tepung jagung. Sebelum sampai pada tahap komersialisasi, diperlukan analisis preferensi. Penelitian yang dilaksanakan bertujuan (1) mengevaluasi penilaian responden terhadap mutu sensori; dan (2) menentukan tingkat preferensi pedagang dan konsumen terhadap mi basah jagung. Data diperoleh melalui wawancara langsung kepada responden yang dipilih dengan penarikan metode contoh purposif. Responden terdiri dari 20 pedagang mi bakso keliling di sekitar Kampus IPB Dramaga dan 100 konsumen mi bakso yang mengonsumsi mi bakso di tempat para pedagang berjualan. Data dianalisis dengan metode tabel frekuensi, uji peringkat bertanda Wilcoxon dan uji Kruskal-Wallis. Penilaian pedagang dan konsumen terhadap atribut mutu sensori (rasa, aroma, tekstur, warna, rasa tertinggal) dan penerimaan secara keseluruhan mi basah jagung berkisar antara biasa (skor 3) dan agak suka (skor 4). Usia, pengalaman berdagang dan cara pemasakan sesaat sebelum penyajian pedagang mi bakso tidak berpengaruh nyata terhadap penilaian. Sementara itu usia, daya beli dan frekuensi responden dalam mengonsumsi mi bakso juga tidak berpengaruh terhadap penilaian. Sebagian besar pedagang $(85 \%)$ dan konsumen $(72 \%)$ mi bakso belum pernah mengenal mi basah jagung. Sebanyak $80 \%$ konsumen menyatakan mi basah jagung cocok untuk produk mi bakso. Preferensi responden ditunjukkan dari $85 \%$ pedagang dan $87 \%$ konsumen mi bakso menyatakan bersedia menggunakan mi basah jagung.
\end{abstract}

Kata kunci: mi basah jagung, teknologi ekstrusi, preferensi konsumen, pedagang mi bakso

\begin{abstract}
Corn wet noodle produced by an extrusion technology is easily applicable in a small scale industry due to its low investment and simple technology and can use to produce corn wet or dried noodles using $100 \%$ corn flour. Consumer perception of wet corn noodle is an important step prior to its commercialization. The research aimed to evaluate sensory acceptance and consumer preferences of corn wet noodle according to consumers and vendor opinion. Data was collected through direct interviews to respondents selected by a purposive sampling method. Respondents consisted of 20 meatball noodle vendor and 100 consumers. Data were analyzed with frequency tables, Wilcoxon rank test, and the Kruskal-Wallis test. Sensory attributes (flavor, aroma, texture, color, and aftertaste) and overall acceptance of the corn wet noodles were evaluated. The results showed that the sensory scores of corn wet noodle ranged from neutral (score 3) to slightly liked (score 4). Age, trading experience, and cooking procedure before serving of vendors did not have any significant effect to sensory product acceptance. Similarly, age, purchasing power, and the frequency of consumers in eating meatball noodles did not influence the product acceptance. The majority of vendors (85\%) and consumers $(72 \%)$ did not recognize wet noodle corn. As many as $80 \%$ of consumers stated that wet corn noodles were suitable for corn
\end{abstract}

Korespondensi:

*) Departemen ITP, FATETA IPB. Jl. Kamper, Kampus IPB Darmaga, Bogor 16680; e-mail: hnpalupi@yahoo.com 
meatball noodle. $85 \%$ of vendors and $87 \%$ of consumers were willing to declare corn wet noodles in meatball noodle selling.

Key words: consumer's preference, corn wet noodle, extrusion technology, meat ball vendor

\section{PENDAHULUAN}

Diversifikasi pangan berbasis sumber daya lokal melalui pengembangan produk mi jagung merupakan salah satu terobosan yang patut dipertimbangkan dalam mengatasi kerawanan pangan. Beberapa daerah di Indonesia merupakan daerah sentra produksi jagung yang berpotensi sebagai pemasok bahan baku untuk pembuatan mi jagung. Pengembangan teknologi mi jagung telah banyak dipelajari, yaitu dengan menerapkan teknologi kalendering (Kusnandar et al. 2009; Palupi et al. 2010) dan juga teknologi ektrusi (Muhandri dan Subarna 2009; Muhandri et al. 2011; Subarna et al. 2012; Muhandri, Subarna dan Palupi. 2013).

Perbedaan utama proses produksi mi dari $100 \%$ tepung jagung dibandingkan mi terigu adalah adanya tahapan pengukusan adonan sebelum proses pembentukan lembaran adonan dan untaian mi (sheeting dan slitting). Hal ini disebabkan pembentukan lembaran adonan tepung jagung bukan ditentukan oleh peranan protein gluten, tetapi oleh pati tergelatinisasi yang berperan sebagai pengikat adonan (Kusnandar et al., 2009). Teknologi kalendering hanya cocok digunakan untuk menghasilkan mi basah jagung yang terbuat dari $100 \%$ tepung jagung, sedangkan apabila dibuat mi kering akan mudah hancur ketika dimasak. Untuk mengatasi hal tersebut, teknologi ekstrusi dapat diterapkan untuk membuat mi jagung basah maupun kering dari tepung jagung $100 \%$. Jika dibandingkan dengan teknologi kalendering, teknologi ekstrusi mempunyai keunggulan cocok diaplikasikan untuk industri kecil karena investasi terjangkau dan dapat digunakan untuk produksi mi jagung, terutama jenis mi basah.

Dalam aplikasinya, Hatorangan (2007) menunjukkan bahwa mi basah jagung yang diproduksi melalui teknologi ekstrusi dengan formulasi dan kondisi proses optimum lebih disukai dibandingkan dengan mi gleser dan spaghetti yang ada di pasaran. Keunggulan mi basah jagung akan lebih bermanfaat, apabila penggunaannya disesuaikan dengan segmen tertentu (Rianto, 2006). Sebagai contoh, warna kuning alami mi basah jagung dapat menambah daya tarik makanan tradisional seperti mi bakso. Proses produksi mi basah jagung dengan teknologi ekstrusi ini kemudian dikembangkan lebih lanjut dan disempurnakan oleh Muhandri (2008) dan menunjukkan potensi yang sangat baik. Sebelum melangkah pada analisis kelayakan bisnisnya, penting diketahui tingkat preferensi masyarakat terhadap mi basah jagung teknologi ekstrusi. Analisis preferensi yang dimaksud diperlukan untuk mengetahui kelayakan mi basah jagung teknologi ekstrusi untuk dipasarkan serta menentukan karakteristik pedagang dan konsumen yang cocok sebagai target pemasarannya. Palupi et al. (2010) mengemukakan bahwa pedagang dan konsumen mi bakso dapat menerima mi basah jagung substitusi 35\% dan karakteristik mi dinilai tidak berbeda dibandingkan mi terigu. Sebanyak $85 \%$ pedagang $\mathrm{mi}$ bakso menyatakan bersedia menggunakan dan $87 \%$ konsumen mi bakso bersedia mengonsumsi mi basah jagung substitusi. Untuk itu penting dilakukan analisis preferensi konsumen terhadap mi basah jagung yang dibuat dari $100 \%$ tepung jagung menggunakan teknologi ekstrusi.

Berdasarkan riset sebelumnya dan beberapa hal yang telah dikemukakan, produk mi bakso dipilih sebagai bentuk penyajian mi basah jagung yang dihasilkan melalui teknologi ekstrusi. Oleh karena mutu mi basah jagung akan sangat berpenga-ruh terhadap kualitas mi bakso secara keseluruhan, maka diperlukan karakteristik sensori (rasa, tekstur, warna dan aroma) mi basah jagung yang dapat diterima oleh konsumen. Sehubungan dengan itu, penelitian yang dilaksanakan ini bertujuan (1) mengevaluasi penilaian responden terhadap mutu sensori mi basah jagung; dan (2) menentukan tingkat preferensi pedagang dan konsumen terhadap mi basah jagung.

\section{METODOLOGI}

Bahan utama yang digunakan dalam penelitian ini berupa kuesioner untuk melakukan survei preferensi konsumen dan pedagang mi bakso terhadap mi basah jagung teknologi ekstrusi. Kuesioner disusun untuk memperoleh data preferensi konsumen terhadap mi basah 
jagung yang diperkenalkan sebagai alternatif $\mathrm{mi}$ basah dari terigu. Bahan baku yang digunakan dalam proses produksi tepung dan mi jagung antara lain jagung pipil varietas P-21 (diperoleh dari petani di daerah Ponorogo), air dan garam. Peralatan yang digunakan antara lain hammer mill, disc mill, vibrator screen 100 mesh, oven (cabinet dryer, tipe GmbH 6072 Germany), timbangan, steamer dan ekstruder pencetak ulir tunggal.

Penelitian dibagi ke dalam tiga tahap, yaitu (1) produksi tepung jagung; (2) produksi mi basah jagung; dan (3) survei preferensi konsumen dan pedagang mi bakso.

\section{Produksi tepung jagung}

Tepung jagung dibuat berdasarkan metode yang telah dikembangkan sebelumnya (Putra 2008). Pro-ses produksi tepung jagung didahului dengan proses penggilingan jagung pipil kering menggunakan hammer mill dengan saringan 10 mesh, sehingga menghasilkan butiran jagung (grits), hancuran lembaga, tip cap dan kulit. Lembaga, tip cap, dan kulit merupakan bagian yang tidak diinginkan dan selanjutnya dipisahkan dengan cara mengambangkan dalam air.

Grits jagung hasil proses pemisahan kemudian ditiris dan dikeringkan dalam oven (cabinet dryer) pada suhu $60{ }^{\circ} \mathrm{C}$ hingga kadar air (KA) 35\% (1-2 jam). Setelah itu, grits jagung digiling menggunakan disc mill dengan saringan 60 mesh. Tepung jagung kasar yang dihasilkan kemudian dikeringkan lagi di dalam oven (cabinet dryer) pada suhu $60{ }^{\circ} \mathrm{C}$ hingga kadar air sekitar $10 \%$. Tepung jagung kering yang dihasilkan lalu diayak menggunakan vibrator screen 100 mesh sehingga siap digunakan sebagai bahan baku pembuatan mi basah jagung. Tepung yang tidak langsung digunakan dikemas dalam plastik polietilen dan disimpan dalam freezer pada suhu sekitar $-10{ }^{\circ} \mathrm{C}$.

\section{Produksi mi jagung basah}

Produksi mi basah jagung mengacu metode Muhandri (2008) dan dilaksanakan pada hari yang sama dengan pelaksanaan pengujian preferensi pedagang dan konsumen mi bakso. Pertama-tama dilakukan formulasi dan pembentukan adonan yang terdiri dari air, garam dan tepung jagung. Garam yang digunakan $2 \%(b / b)$ dari bobot tepung jagung, sementara banyaknya air yang digunakan disesuaikan hingga KA adonan sekitar $70 \%$. Adonan yang dihasilkan digulung dengan roller kayu hingga mencapai ketebalan $5 \mathrm{~mm}$. Adonan kemudian dikukus dalam kukusan (steamer) selama 15 menit pada suhu $100{ }^{\circ} \mathrm{C}$. Adonan yang telah meng-alami proses pengukusan pertama segera dicetak menggunakan ekstruder ulir tipe MS9 (Guangdong Henglian Food Machine Co.Ltd.) dengan die yang berdiameter $2 \mathrm{~mm}$, kemudian dipotong dengan panjang $20 \mathrm{~cm}$. Proses pencetakan tersebut menghasilkan mi setengah matang yang memerlukan proses pengukusan kedua selama 15 menit pada suhu $100^{\circ} \mathrm{C}$. Proses pengukusan kedua menghasilkan mi basah jagung matang yang siap digunakan dan dikemas dalam plastik low density polyethylene (LDPE) dengan berat $35 \mathrm{~g}$ per kemasan (setara dengan satu porsi mi bakso).

\section{Survei preferensi konsumen dan pedagang mi bakso}

Segera setelah diproduksi, mi basah jagung dibawa ke pedagang bakso di sekitar kampus IPB. Jeda waktu antara proses produksi hingga selesai pengambilan data adalah 3-5 jam. Untuk keperluan ini, mi basah jagung diproduksi dengan basis $400 \mathrm{~g}$ tepung jagung per hari yang cukup untuk melaksanakan survei kepada 2 pedagang dan 10 konsumen mi bakso. Mi basah jagung disajikan sebagai bagian dari satu porsi mi bakso. Sesaat sebelum disajikan, mi basah jagung mengalami beberapa cara pemasakan sesaat sebelum penyajian, sesuai dengan kebiasaan masingmasing pedagang mi bakso. Perlakuan tersebut tidak dibuat seragam, agar mendekati kondisi yang sesungguhnya terjadi di lapangan.

Survei melalui wawancara dilakukan dalam dua tahap, sebelum dan setelah mengonsumsi mi basah jagung. Sebelum mengonsumsi dilakukan wawancara untuk memperoleh profil dan pendapat umum responden mengenai mi serta faktor-faktor yang mempengaruhi penilaiannya. Sedangkan setelah mengonsumsi responden diminta menilai karakteristik sensori produk dan kesediaan responden untuk menggunakan mi basah jagung. Penilaian atribut mutu sensori dan mutu keseluruhan mi basah jagung dengan menggunakan skala1 (tidak suka), 2 (kurang suka), 3 (biasa), 4 (agak suka), dan 5 (suka). Skala nilai "biasa" pada hasil pengujian disetarakan dengan nilai "sama dengan" mi terigu.

\section{Pengumpulan dan analisis data}

Penelitian ini merupakan penelitian eksploratif, sehingga tidak membatasi responden pada cakupan populasi tertentu dan menggunakan data primer yang diperoleh secara langsung dari para responden. Responden dipilih menggunakan metode purposive sampling, yaitu 20 pedagang mi 
bakso keliling yang berdagang di sekitar Kampus Institut Pertanian Bogor (IPB) Dramaga dan 100 konsumen mi bakso (10 konsumen per pedagang) di tempat para pedagang berjualan. Responden pedagang mi bakso dipilih atas dasar kedekatan lokasi berdagangnya dengan Kampus IPB untuk memudahkan teknis pelaksanaan. Responden konsumen mi bakso dipilih secara acak dari pelanggan pedagang bakso. Pengumpulan data dilakukan dengan metode wawancara langsung melalui pertanyaan tertutup dan terbuka.

Analisis data dilakukan menggunakan metode statistik deskriptif dan inferensia non parametrik. Data dianalisis dengan metode tabel frekuensi, uji peringkat bertanda Wilcoxon dan uji Kruskal-Wallis. Uji peringkat bertanda Wilcoxon digunakan untuk menganalisis adanya perbedaan dari dua data hasil pengamatan yang berpasangan dengan tipe data interval atau rasio. Uji Kruskal-Wallis adalah uji non-parametrik yang digunakan untuk membandingkan tiga atau lebih kelompok data yang terdistribusi bebas (tidak normal) dan ditarik dari populasi secara acak. Pengolahan data dilakukan dengan bantuan perangkat lunak Statistical Package for Social (SPSS) 16, dan uji Wilcoxon menggunakan perangkat lunak Minitab 14.

\section{HASIL DAN PEMBAHASAN}

\section{Preferensi pedagang mi bakso}

\section{Profil Responden}

Seluruh pedagang mi bakso yang terlibat dalam penelitian ini adalah laki-laki. Sebagian besar (45\%) responden berusia 36-45 tahun, 25\% berusia $16-25$ tahun, $15 \%$ berusia $26-35$ tahun, $10 \%$ berusia $46-55$ tahun, dan $5 \%$ berusia $>55$ tahun (Gambar 1). Dengan demikian dapat dikatakan sebagian besar pedagang mi bakso berada pada rentang usia produktif.

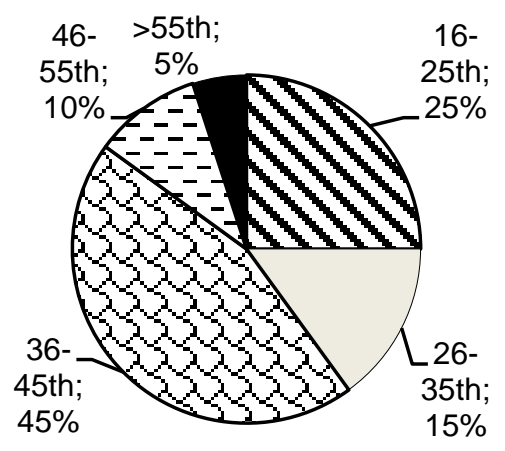

Gambar 1. Usia responden pedagang mi bakso
Responden mempunyai pengalaman berdagang mi bakso yang bervariasi dan dapat dikelompokkan menjadi $45 \%$ mempunyai pengalaman berdagang selama 0-9 tahun, $40 \%$ berpengalaman selama > 20 tahun, dan $15 \%$ berpengalaman selama 10-19 tahun (Gambar 2).

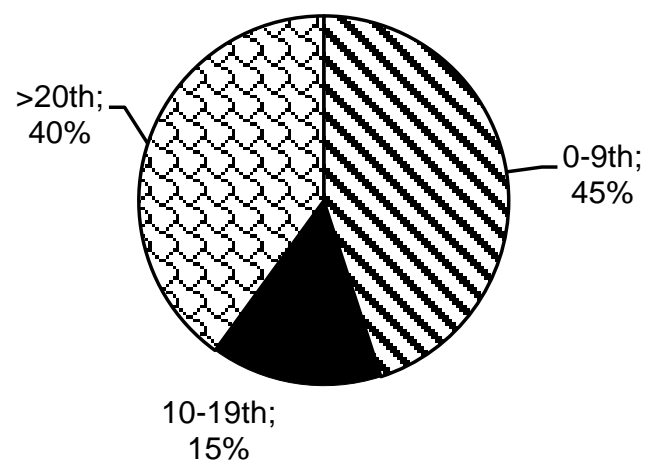

Gambar 2. Pengalaman berjualan pedagang mi bakso

\section{Penilaian responden terhadap mutu sensori mi basah jagung}

Gambar 3 memperlihatkan penilaian pedagang mi bakso terhadap atribut mutu sensori mi basah jagung berkisar antara 3 (biasa) hingga 4 (agak suka). Analisis lebih lanjut menggunakan uji peringkat bertanda Wilcoxon menunjukkan bahwa rasa, aroma dan kesukaan secara keseluruhan mempunyai nilai (3,5-4) berbeda dengan tiga atribut mutu sensori yang lain, yaitu tekstur, warna dan rasa tertinggal (3-3,5). Tekstur, warna dan rasa tertinggal memiliki nilai $\mathrm{P}>$ (1) () 0.05 sehingga dinyatakan bahwa nilai ketiga atribut mutu sensori tersebut sama dengan nilai batas minimal, yaitu 3 (Gambar 3). Hasil tersebut bermakna bahwa ketiga atribut mutu mi basah jagung masih dapat diterima oleh pedagang mi bakso, akan tetapi pada tingkat kesukaan minimal.

Mi basah jagung teknologi ekstrusi memiliki nilai kekerasan dan kekenyalan yang cenderung lebih tinggi dibandingkan dengan mi terigu yang biasa digunakan. Hal tersebut memberikan karakteristik yang dikehendaki pada produk mi bakso, seperti tekstur tidak membengkak, tidak terlalu lembek dan tidak patah-patah. Karakteristik tersebut dapat berpengaruh positif atau negatif pada penilaian responden terkait dengan selera dan kesukaan secara individu terhadap tekstur. Namun demikian tekstur mi basah jagung masih dinilai wajar dan dapat diterima oleh responden. 


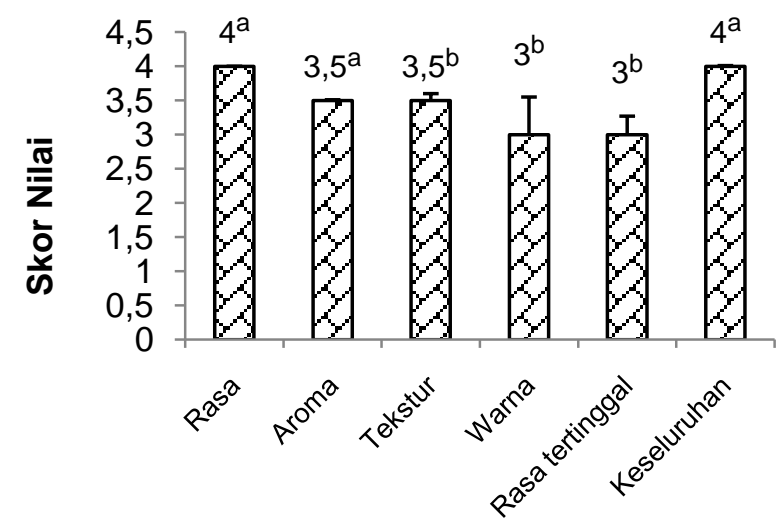

Gambar 3. Penilaian pedagang mi bakso (n=20) terhadap mutu sensori mi basah jagung berdasarkan uji peringkat bertanda Wilcoxon (ㅇ) 우 0.05).

Secara visual intensitas warna kuning mi jagung lebih tinggi dibandingkan dengan mi terigu. Selain itu, warna kuning ini juga tidak luntur pada saat penyajian bersama kuah bakso. Di sisi lain, karakteristik warna ini dapat memberikan dampak negatif terhadap preferensi responden jika warna kuning tersebut diduga berasal dari pewarna sintetis atau pewarna yang dilarang digunakan. Namun, hasil uji peringkat bertanda Wilcoxon menunjukkan bahwa atribut warna mi basah jagung teknologi ekstrusi masih dapat diterima oleh responden. Jika informasi bahwa warna mi basah jagung adalah warna alami dan baik dari segi kesehatan diberikan kepada responden, maka penilaiannya terhadap atribut warna mi basah jagung diduga dapat meningkat.

Di sisi lain, hasil analisis terhadap penilaian atribut rasa tertinggal menunjukkan bahwa setelah menelan produk mi jagung, responden tidak merasakan adanya rasa tertinggal yang mengganggu, seperti sensasi berpasir (sandy) dan sisa mi yang melekat pada rongga mulut.

\section{Preferensi Responden}

Preferensi responden terhadap suatu produk dipengaruhi oleh beberapa faktor antara lain tingkat pengenalan terhadap produk, kebiasaan penggunaan, dan kecocokan dalam penggunaan. Faktor-faktor tersebut yang akhirnya menentukan keputusan responden untuk membeli atau menggunakan produk tersebut (Tabel 1).

Tabel 1 menunjukkan bahwa sebagian besar $(85 \%)$ pedagang $\mathrm{mi}$ bakso belum pernah mengenal atau mendapatkan informasi mi basah jagung. Sementara itu responden yang lain (15\%) menyatakan pernah mendengar tentang $\mathrm{mi}$ jagung, ketika pernah terlibat dalam kegiatan sosialisasi mi jagung yang dilakukan oleh IPB. Rendahnya tingkat pengenalan responden terhadap mi jagung disebabkan produk ini masih relatif baru dan belum dikomersialisasikan. Dengan demikian, apabila sosialisasi dilakukan secara terus menerus dan disertai dengan informasi cukup tentang keunggulan-keunggulannya, seperti nilai gizi dan manfaat terhadap kesehatannya, sangat dimungkinkan preferensi responden terhadap mi jagung dapat menjadi lebih baik. Stepherd dan Spark (1994) menyatakan bahwa pengetahuan tentang produk akan mempengaruhi preferensi pangan. Selain itu nilai tambah suatu produk akan meningkatkan preferensi konsumen (Banterle, Cavalierce dan Ricci, 2012). Pada umumnya pengenalan produk baru kepada konsumen membutuhkan waktu yang sama halnya dengan pengembangan inovasi teknologinya (Earle \& Earle, 2008).

Tabel 1. Faktor yang memengaruhi preferensi responden terhadap mi jagung

Faktor yang berpengaruh Jumlah $\begin{gathered}\text { Persentase } \\ (\%)\end{gathered}$

\begin{tabular}{lcc}
\hline Pengenalan mi basah jagung & & \\
- pernah mendengar & 3 & 15 \\
- belum pernah mendengar & 17 & 85 \\
\hline
\end{tabular}

Jenis mi yang digunakan

\begin{tabular}{lcc} 
- mi instan curah & 17 & 85 \\
- mi instan curah \& mi kuning & 3 & 15 \\
\hline
\end{tabular}

Perlakuan dalam penggunaan

- dicelup beberapa kali dalam ai: $\quad 7 \quad 35$ rebusan bakso

- direbus $<2$ menit $\quad 5 \quad 25$

- direbus $>2$ menit $\quad 8 \quad 40$

Kesediaan menggunakan

\begin{tabular}{lcc} 
- bersedia & 17 & 85 \\
- tidak bersedia & 3 & 15 \\
\hline
\end{tabular}

Berdasarkan hasil wawancara, seluruh pedagang mi bakso menggunakan mi instan curah yang diperoleh dari pasar. Hanya terdapat $15 \%$ pedagang yang menggunakan tambahan $\mathrm{mi}$ basah/kuning yang juga diperoleh dari pasar. Hal ini sangat beralasan karena mi instan mempunyai tingkat keawetan dan kepraktisan yang lebih baik dibandingkan mi basah. Pada umumnya mi instan yang mempunyai KA 5-8\% akan memiliki daya simpan yang cukup lama (Astawan, 1999).

Pada umumnya pedagang mi bakso memiliki cara pemasakan tertentu sesaat sebelum 
penyajian. Berdasarkan observasi peneliti, perlakuan penyajian tersebut dapat dikategorikan menjadi tiga, yaitu (1) dicelupkan beberapa kali ke dalam air rebusan bakso; (2) direbus dalam kuah bakso selama kurang dari 2 menit; dan (3) direbus dalam kuah bakso selama lebih dari 2 menit. Hasil survei pada 20 pedagang mi bakso menunjukkan bahwa 8 (40\%) responden mengolah mi basah jagung dengan cara perebusan di dalam kuah bakso selama lebih dari dua menit; 7 (35\%) pedagang mengolah dengan pencelupan beberapa kali dalam kuah rebusan bakso; dan 5 $(25 \%)$ pedagang mengolah dengan perebusan selama kurang dari dua menit. Secara umum, lama pemasakan akan berpengaruh terhadap karakteristik mutu sensori produk pangan yang akan berkaitan dengan preferensi responden terhadap produk secara keseluruhannya. Berdasarkan hasil tersebut direkomendasikan pemasakan mi basah jagung dilakukan dengan perebusan di dalam kuah bakso selama lebih dari dua menit.

Hasil uji Kruskal-Wallis terhadap cara pemasakan sesaat sebelum penyajian menunjukkan bahwa nilai $\mathrm{P}>$ ○๑0.05, yang berarti nilai kesukaan terhadap kualitas mi basah jagung secara keseluruhan sama untuk ketiga cara pemasakan. Kesukaan yang sama antara tiga perlakuan pemasakan diduga disebabkan oleh adanya pendapat subyektif dari masing-masing pedagang mi bakso ketika menentukan waktu pemasakan yang tepat. Responden cenderung memberikan penilaian yang tinggi pada perlakuan pengolahan mi yang dianggap tepat.

Selain faktor-faktor yang telah disebutkan, faktor terpenting yang berhubungan langsung dengan atribut mutu sensori produk mi basah jagung adalah kesediaan responden untuk menggunakan produk mi basah jagung. Hasil survei menunjukkan sebanyak 17 responden $(85 \%)$ menyatakan bersedia menggunakan $\mathrm{mi}$ basah jagung sebagai produk subtitusi dari mi terigu yang sudah biasa digunakan, sementara itu 3 responden (15\%) menyatakan tidak bersedia.

\section{Preferensi konsumen mi bakso}

\section{Penilaian Responden terhadap}

Konsumen mi bakso yang terlibat sebagai respon-den berjumlah 100 orang, terdiri dari 68 perempuan dan 32 laki-laki. Sebagian besar komsumen mi bakso (42\%) berusia 16-15 tahun; $22 \%$ berusia $26-35$ tahun, $19 \%$ berusia 36-45 tahun, $7 \%$ berusia $<15$ tahun, $6 \%$ berusia $46-55$ tahun, dan $4 \%$ berusia $>55$ tahun (Gambar 4). Dengan demikian diduga bahwa sebagian besar konsumen mi bakso adalah mahasiswa (19-25 tahun yang tinggal di sekitar kampus, mengingat pedagang bakso yang disurvei berlokasi di sekitar kampus.

Mayoritas responden (37\%) mempunyai rata-rata pengeluaran setiap bulan $<500$ ribu rupiah, selanjutnya berturut-turut 500-999 ribu $(32 \%)$, antara $1-1,9$ juta (22\%), antara $2-3,9$ juta serta $>3,9$ jutarupiah. Diagram pie rataan pengeluaran responden setiap bulan dapat dilihat pada Gambar 5. Hal ini menunjukkan bahwa mi bakso termasuk makanan yang relatif terjangkau oleh responden dengan rataan pengeluaran per bulan relatif kecil.

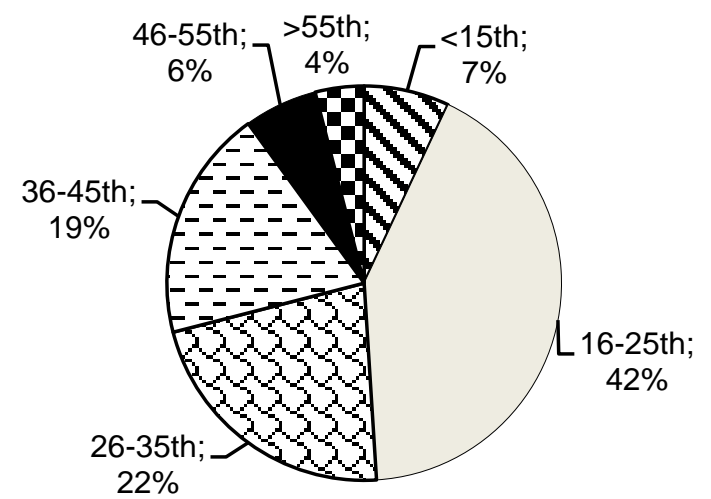

Gambar 4. Distribusi konsumen mi bakso berdasarkan usia $(\mathrm{n}=100)$

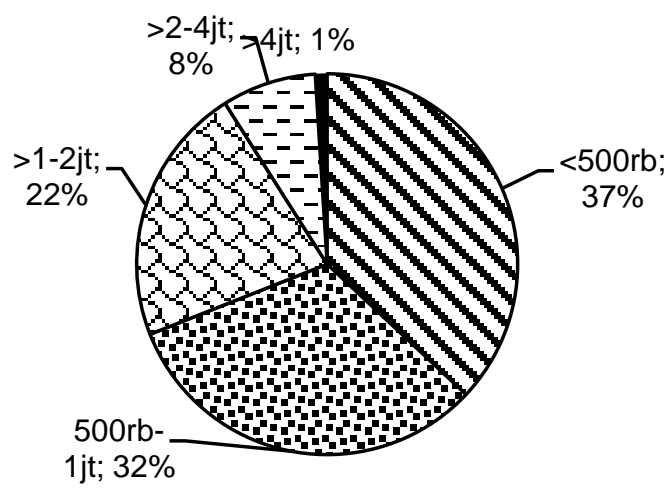

Gambar 5. Rataan pengeluaran konsumen mi bakso per bulan $(n=100)$

Berdasarkan kategori pekerjaan, responden terdiri dari mahasiswa atau pelajar, yaitu $34 \%$. Setelah itu berturut-turut adalah ibu rumah tangga (29\%), wirausahawan (17\%), tidak bekerja $(8 \%)$, pegawai swasta $(6 \%)$, lain-lain $(4 \%)$ dan pegawai negeri sipil (2\%). Sebaran jenis pekerjaan responden tentunya dipengaruhi oleh waktu pelaksanaan survei yang berkisar antara pukul 
13.00-18.00 WIB, sehingga jenis pekerjaan yang memiliki waktu kerja terikat seperti pegawai negeri sipil dan pegawai swasta cenderung memiliki persentase kecil (Gambar 6).

Frekuensi konsumen mengonsumsi mi bakso dalam sepekan adalah 3-5 kali (42\%), 1-2 kali $(38 \%)$, dan lebih dari 5 kali $(20 \%)$. Hasil ini menunjukkan sebagian besar responden cukup sering mengonsumsi mi bakso, yaitu 3-5 kali dalam satu pekan. Hal ini sejalan dengan penelitian Juniawati (2003) yang mengemukakan bahwa mi merupakan produk yang sering dikonsumsi sebagai makanan sarapan maupun sebagai makanan selingan. Frekuensi konsumen mengonsumsi mi bakso dalam sepekan dapat dilihat pada Gambar 7.

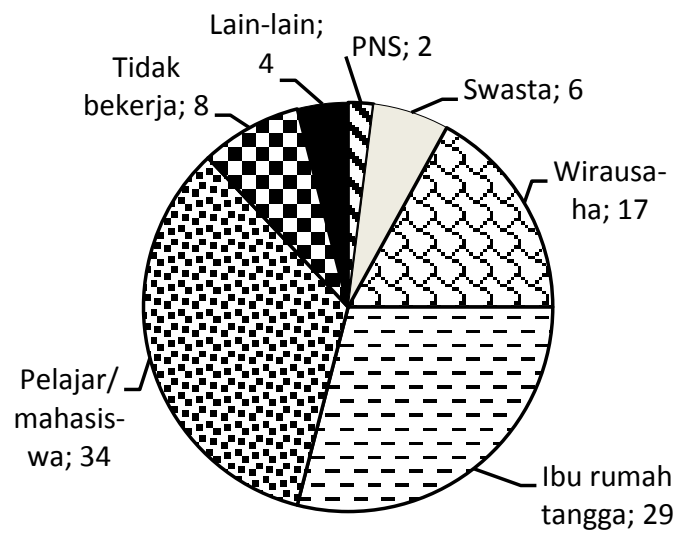

Gambar 6. Pekerjaan konsumen mi bakso $(n=100)$

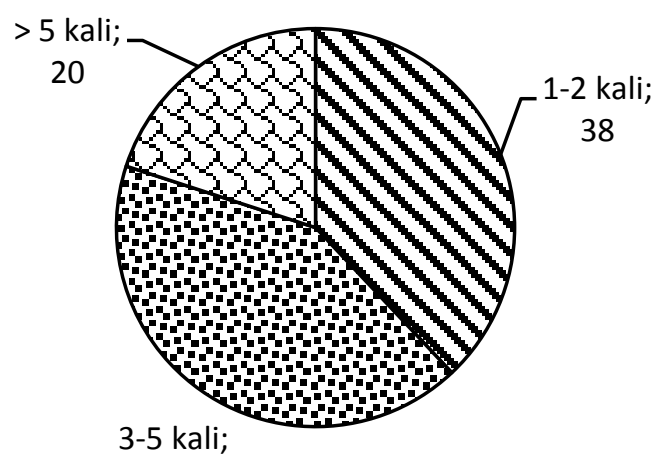

42

Gambar 7. Frekuensi responden mengkonsumsi mi bakso dalam sepekan $(n=100)$

Penilaian responden terhadap mutu sensori mi basah jagung

Penilaian konsumen terhadap atribut mutu sensori (rasa, aroma, tekstur, warna dan rasa tertinggal) dan penerimaan secara keseluruhan mi basah jagung berkisar antara biasa (skor 3) dan agak suka (skor 4). Analisis pembedaan menggunakan uji peringkat bertanda Wilcoxon (Gambar 8) menunjukkan bahwa nilai kesukaan minimal oleh responden adalah 3 (biasa). Hasil uji lanjut Kruskal-Wallis menunjukkan bahwa nilai $P$ $<$ () 0,05 untuk semua atribut mutu sensori dan penerimaan keseluruhan mi basah jagung yang berarti nilai semua atribut mutu sensori tidak sama dengan nilai batas minimal 3 (rasa tertinggal). Dengan demikian dapat dapat disimpulkan bahwa semua atribut mutu sensori dan mutu secara keseluruhan berbeda dengan batas minimal penerimaan konsumen pada atribut rasa tertinggal (3).

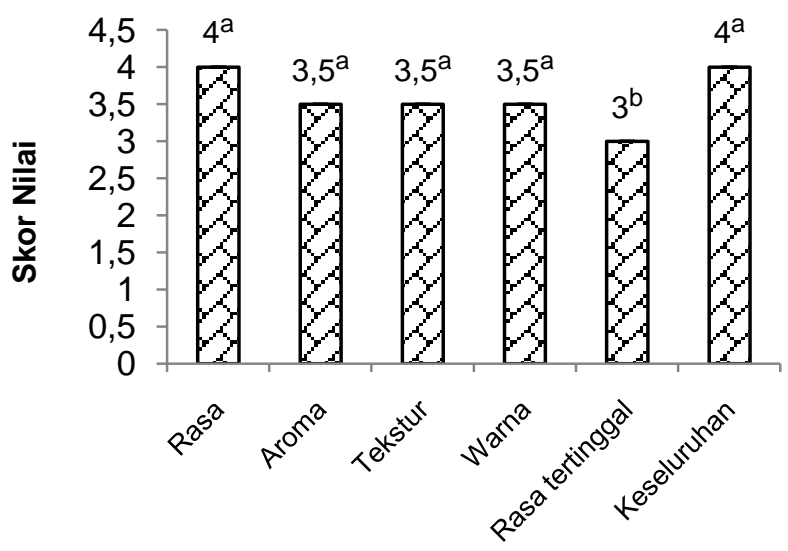

Gambar 8. Penilaian konsumen mi bakso (n=100) terhadap mutu sensori mi basah jagung berdasarkan uji peringkat bertanda Wilcoxon (๑ 0.05)

Hasil ini memperlihatkan bahwa responden de-ngan karakteristik sebagaimana yang telah dijabarkan sebelumnya memiliki tingkat kesukaan yang lebih terhadap mi basah jagung, bila dibandingkan dengan mi terigu yang biasa digunakan. Beberapa hal yang dapat menjadi penyebab antara lain rasa yang sedikit asin dan gurih, aroma yang tidak berbau kapur, tekstur yang kenyal dan tidak mudah patah, rasa tertinggal yang tidak mengganggu setelah mi ditelan, serta intensitas warna kuning yang masih bisa diterima oleh responden. Dari sisi bisnis, hasil tersebut cukup menguatkan produk mi basah jagung untuk dikembangkan lebih lanjut.

Kesimpulan ini saling menguatkan dengan berbagai hasil analisis yang lain. Pada analisis preferensi pedagang mi bakso, atribut rasa juga merupakan atribut utama penyebab meningkatnya nilai kesukaan secara keseluruhan mi basah jagung, sehingga dapat disimpulkan bahwa persepsi antara kedua populasi responden relatif tidak berbeda. Pada uji peringkat bertanda 
Wilcoxon, nilai p penilaian responden konsumen mi bakso terhadap atribut rasa dan mutu keseluruhan adalah sama, dengan demikian atribut rasa berperan besar dalam menentukan mutu mi basah jagung secara keseluruhan.

\section{Preferensi responden terhadap mi basah jagung}

Pengetahuan responden terhadap produk merupakan salah satu faktor yang akan mempengaruhi preferensinya terhadap mi basah jagung, sebagaimana telah dijelaskan sebelumnya. Faktorfaktor lain yang mempengaruhi preferensi konsumen mi bakso terhadap mi basah jagung dapat dilihat pada Tabel 2.

Pada Tabel 2 dapat dilihat bahwa sebagian besar responden belum pernah mendengar dan mendapat informasi mengenai mi jagung. Berdasarkan hasil wawancara yang lebih mendalam diketahui bahwa hampir seluruh responden yang pernah mendengar informasi mengenai mi jagung adalah pelajar atau mahasiswa. Pada dasarnya konsumen memerlukan informasi terkait pangan yang akan dikonsumsinya. Pencarian informasi dapat dilakukan melalui dua cara, yaitu secara internal berdasarkan ingatan (informasi dari diri sendiri) dan secara eksternal baik melalui sumber pribadi seperti keluarga atau teman, maupun sumber komersial seperti melalui iklan atau promosi (Bardhani, Zakaria dan Palupi, 2009). Oleh karena itu kegiatan sosialisasi mi basah jagung masih diperlukan khususnya bagi masyarakat umum. Sosialisasi tentang kelebihan dan keunggulan produk dapat dijadikan wahana untuk lebih mengenalkan produk tersebut sehingga dapat meningkatkan preferensi konsumen. Kelebihan mi jagung basah yang dapat diunggulkan antara tidak memerlukan penggunaan pewarna sintetis (pada umumnya mi terigu menggunakan pewarna kuning), mengandung betakaroten, dan bukan berasal dari bahan impor.

Dengan karakter khas yang dimiliki mi basah jagung, tentunya akan memengaruhi kecocokan pada produk-produk olahan tertentu dalam penggunaannya. Produk olahan yang biasanya menggunakan mi basah, antara lain mi bakso, mi ayam dan soto mi. Hasil evaluasi kecocokan mi basah jagung menunjukkan bahwa sebagian besar responden $(80 \%)$ menyatakan $\mathrm{mi}$ basah jagung cocok digunakan dalam produk mi bakso, sementara itu 20\% lainnya menyatakan tidak cocok. Hal yang diidentifikasi menyebabkan kecocokan penggunaannya dalam mi bakso adalah warna kuning mi jagung dan tidak tidak luntur dalam kuah bakso, aroma yang tidak berbau kapur, teksturnya yang lebih keras dan tidak mudah patah, serta karakteristiknya yang tidak menyerap air dengan cepat, sehingga menyebabkan terlalu lunak. Meskipun sebagian besar responden menilai mi basah jagung cocok digunakan untuk produk mi bakso, namun melalui pertanyaan terbuka responden merekomendasikan penggunaannya pada produk olahan lain seperti mi ayam $(36,4 \%)$, soto mi $(32,6 \%)$, dan $\mathrm{mi}$ goreng $(12,4 \%)$.

Tabel 2. Faktor yang mempengaruhi preferensi responden terhadap mi jagung

\begin{tabular}{lcc}
\hline \multicolumn{1}{c}{ Faktor yang berpengaruh } & Jumlah & $\begin{array}{c}\text { Persentase } \\
(\mathbf{\%})\end{array}$ \\
\hline $\begin{array}{l}\text { Pengenalan mi basah jagung } \\
\text { - pernah mendengar }\end{array}$ & 28 & 28 \\
- belum pernah mendengar & 72 & 72 \\
\hline Kecocokan digunakan untuk & & \\
mi bakso & & \\
- cocok & 80 & 80 \\
- tidak cocok & 20 & 20 \\
\hline Kesediaan untuk konsumsi & & \\
- bersedia & 87 & 87 \\
- tidak bersedia & 13 & 13 \\
\hline
\end{tabular}

Hasil survei kesediaan responden untuk menggunakan mi basah jagung menunjukkan bahwa sebagian besar responden $(87 \%)$ menyatakan bersedia menggunakan mi basah jagung sebagai produk subtitusi atau komplemen mi terigu yang selama ini biasa digunakan. Hal ini sesuai dengan hasil penilaian responden bahwa semua atribut mutu sensori mi basah jagung dan mutu secara keseluruhannya dapat diterima. Hasil ini sejalan dengan kesediaan pedagang mi bakso (85\%) untuk menggunakan $\mathrm{mi}$ basah jagung. Dengan demikian, pedagang dan konsumen mi bakso mempunyai preferensi relatif sama dalam hal penggunaan mi basah jagung pada produk mi bakso.

\section{KESIMPULAN}

Penilaian pedagang dan konsumen terhadap atribut mutu sensori (rasa, aroma, tekstur, warna dan rasa tertinggal) dan penerimaan secara keseluruhan mi basah jagung berkisar antara biasa (skor 3) dan agak suka (skor 4). Usia, pengalaman berdagang, dan cara pemasakan sesaat sebelum penyajian pedagang mi bakso tidak berpengaruh nyata (๑ 0.05) terhadap penilaian. Sementara itu usia, daya beli, 
dan frekuensi responden dalam mengonsumsi mi bakso tidak berpengaruh meliputi.

Sebagian besar pedagang (85\%) dan konsumen (72\%) mi bakso belum pernah mengenal $\mathrm{mi}$ basah jagung. Hampir seluruh pedagang mi bakso menggunakan mi instan curah dan menilai mutu mi basah jagung tidak dipengaruhi cara pemasakan sesaat sebelum penyajian. Sebanyak $80 \%$ konsumen menyatakan mi basah jagung cocok untuk produk mi bakso. Preferensi responden terhadap mi basah jagung ditunjukkan dari $85 \%$ pedagang dan $87 \%$ konsumen mi bakso menyatakan bersedia menggunakan mi basah jagung. Responden juga merekomendasikan penggunaan mi jagung pada produk olahan mi ayam $(36.4 \%)$, soto $\mathrm{mi}(32.6 \%)$, dan $\mathrm{mi}$ goreng $(12.4 \%)$.

\section{DAFTAR PUSTAKA}

Astawan, M. 1999. Membuat Mi dan Bihun. PT. Penebar Swadaya, Jakarta.

Banterle, A., A. Cavaliere, E.C. Ricci. 2012. Food Labelled Information: An Empirical Analysis of Consumer Preferences. Int J Food System Dynamics, 3(2): 156-170.

Bardhani, M.A, F.R. Zakaria, N.S. Palupi. 2009. Analisis Persepsi Konsumen terhadap Produk Minyak Sawit Merah sebagai Minyak Kesehatan (studi kasus perumahan Ciomas Permai, Bogor). Jurnal Manajemen IKM, 4(2): 185-194.

Earle, M., R. Earle. 2008. New Product Development: Systematic Industrial Technology. Earle M, Earle R, editor. Case Studies in Food Prodcut Development, hlm 3-23. Woodhead Publishing Limited, Abington Hall, Cambridge CB21 6 AH, Englad.

Hatorangan, F. Erick. 2007. Pengaruh Perlakuan Konsentrasi $\mathrm{NaCl}$, Kadar Air, dan Passing terhadap Mutu Fisik Mi Basah Jagung yang Diproduksi dengan Menggunakan Ekstruder Ulir Pemasak dan Pencetak. Skripsi. Fakultas Teknologi Pertanian IPB, Bogor.

Kusnandar, F., N.S. Palupi, O.A. Lestari, dan S. Widowati. 2009. Karakterisasi Tepung Jagung Termodifikasi Heat Moisture Treatment (HMT) dan Pengaruhnya terhadap Mutu Pemasakan dan Sensori Mi Jagung Kering. Jurnal Penelitian Pascapanen Pertanian, 6(2), 2009.
Juniawati. 2003. Optimasi Proses Pengolahan Mi Jagung Instan Berdasarkan Kajian Preferensi Konsumen. Skripsi. Fakultas Teknologi Pertanian IPB, Bogor.

Muhandri, T. 2008. Karakterisasi Tepung Berbagai Varietas Jagung Kuning dan Potensinya untuk Dibuat Mi Jagung. Laporan Penelitian Hibah Bersaing. LPPM IPB, Bogor. dan Subarna. 2009. Pengaruh Kadar Air, $\mathrm{NaCl}$ dan Jumlah Passing terhadap Karakteristik Reologi Mi Jagung. Jurnal Teknologi dan Industri Pangan, 20(1): 69-75. A.B. Ahza, R. Syarief, dan Sutrisno. 2011. Optimasi Proses Ekstrusi Mi Jagung dengan Metode Permukaan Respon. Jurnal Teknologi dan Industri Pangan, (2): 97-104. Subarna, N.S. Palupi. 2013. Karakteristik Mi Basah Jagung Akibat Pengaruh Laju Pengumpanan dan Penambahan Guar Gum. J. Teknolologi dan Industri Pangan, 24(1): 110-114.

Palupi, N.S., F. Kusnandar, D.R. Adawiyah, dan D. Syah. 2010. Penentuan Umur Simpan dan Pengembangan Model Diseminasi Dalam Rangka Percepatan Adopsi Teknologi Mi Jagung bagi UKM. Jurnal Manajemen IKM, 5(1): 42-52.

Putra, S.N. 2008. Optimalisasi Formula dan Proses Pembuatan Mi Jagung dengan Metode Kalendering. Skripsi. Fakultas Teknologi Pertanian IPB, Bogor.

Rianto, B.F. 2006. Desain Proses Pembuatan dan Formulasi Mi Basah Berbahan Baku Tepung Jagung. Skripsi. Fakultas Teknologi Pertanian IPB, Bogor.

Stepherd, R. and P. Sparks. 1994. Modelling Food Choice. dalam: MacFie, H.J.H. and D.M.H. Thomson (eds.). Measurement of Food Prefe-rence. pp 202-223. Blackie Academic and Profesional, Glasgow.

Subarna, T. Muhandri , B. Nurtama, dan A.S. Firlieyanti. 2012. Peningkatan Mutu Mi Kering Jagung dengan Penerapan Kondisi Optimum Proses dan Penambahan Monogliserida. Jurnal Teknologi dan Industri Pangan, 13(2): 146-152. 